\title{
TEKNIS PENDAMPINGAN ANAK USIA 5-6 TAHUN DALAM PENGGUNAAN
}

\section{GADGET}

Sriwahyuni Sairo

Sekolah Tinggi Agama Kristen Terpadu Pesat Salatiga

sairoyuni4@gmail.com

\begin{abstract}
In general, gadgets are devices or electronic devices that are relatively small in size and have special and practical functions in their use. Gadgets have a very big influence in human life, because the existence of gadgets can simplify human work, and also make it easier for humans to interact with other people. The research objective is to find out what is a gadget. Gadget Functions. Types of gadgets. Use of Gadgets in Preschool Children. Positive impact and negative impact of using gadgets on children aged 5-6 years. How to teach good use of gadgets for early childhood. Technical assistance for children aged 5-6 years in the use of gadgets. In this writing, using library research. Library research limits its activities to library collection materials only without requiring field research. The results of the literature research show that parents or adults know what gadgets are and the effects of their use, as well as ways to assist children in using gadgets. So that parents do not allow children to play gadgets excessively and without parental supervision.
\end{abstract}

Keywords: Gadgets, positive and negative impact of gadgets, children.

\section{ABSTRAK}

Secara umum, gadget merupakan alat elektronik yang berukuran relatif kecil dan memiliki fungsi khusus serta praktis dalam penggunaannya. Gadget memiliki pengaruh yang sangat besar dalam kehidupan manusia, karena dengan adanya gadget dapat mempermudah pekerjaan manusia, dan juga memberikan kemudahan bagi manusia dalam berinteraksi dengan orang lain. Tujuan penelitian yaitu untuk mengetahu Pengertian Gadget. Fungsi Gadget. Jenis gadget. Penggunaan Gadget Pada Anak Prasekolah. Dampak positif dan dampak negatif penggunaan gadget pada anak usia 5-6 tahun. Cara mengajarkan penggunaan gadget yang baik untuk anak usia dini. Teknis pendampingan anak usia 5-6 tahun dalam penggunaan gadget. Dalam penulisan ini, menggunakan penelitian Pustaka. Riset Pustaka membatasi kegiatannya hanya pada bahan-bahan koleksi perpustakaan saja tanpa 
memerlukan riset lapangan. Hasil dari penelitian kepustakaan yaitu orang tua atau orang dewasa mengetahui apa itu gadget dan dampak-dampak dari penggunaan, serta cara-cara mendampingi anak dalam penggunaan gadget. Sehingga dengan demikian orang tua tidak membiarkan anak bermain gadget berlebihan dan tanpa pengawasan dari orangtua.

Kata kunci: Gadget, dampak positif dan negatif gadget, anak.

\section{Pendahuluan}

Secara umum, gadget adalah perangkat atau alat elektronik yang berukuran relatif kecil serta memiliki fungsi khusus dan praktis dalam penggunaannya. ${ }^{1}$ Berikut ini adalah grafik peningkatan penggunaan gadget khususnya Smartphone dari tahun 2015-tahun 2025.

\section{Pengguna Smartphone diperkirakan Mencapai 89\% Populasi pada 2025}

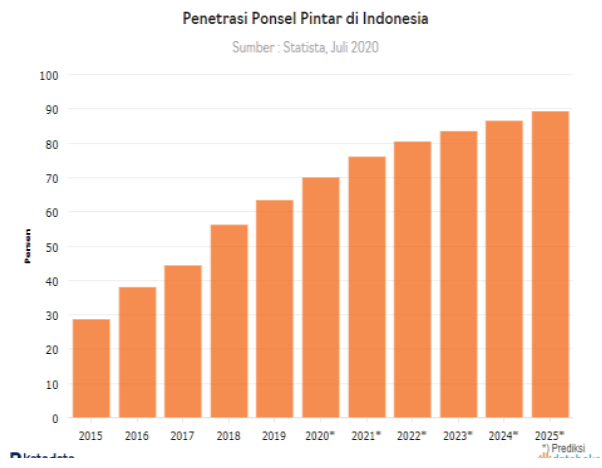

Dari grafik di atas dapat diketahui bahwa penggunaan smartphone, khususnya di Indonesia sudah meningkat dari tahun ke tahun. Jumlah pengguna Smartphone di
Indonesia pada tahun 2021 telah mencapai 75\% Populasi, dan di perkirakan pada tahun 2025 pengguna Smartphone akan mencapai $89 \%$ populasi. ${ }^{2}$

Gadget memiliki pengaruh yang sangat besar dalam kehidupan manusia, karena dengan adanya gadget dapat mempermudah pekerjaan manusia, dan juga memberikan kemudahan bagi manusia dalam berinteraksi dengan orang lain. Memang gadget memiliki banyak sekali manfaat jika dipergunakan dengan tujuan yang baik, tetapi jika orang yang menggunakan gadget tidak bisa menggunakannya untuk hal-hal yang bermanfaat maka gadget juga bisa berpengaruh buruk bagi kehidupan manusia. Pada zaman sekarang ini gadget tidak hanya digunakan oleh orang tua atau orang dewasa, tetapi anak-anak yang masih kecilpun sudah mahir dalam penggunaan

\footnotetext{
${ }^{2}$ https://www.google.com/
}

\footnotetext{
${ }^{1}$ Monografi Fenomena Kecanduan Gadget Pada Anak Usia Dini (surabaya, 2020), 13.
} 
gadget, bahkan faktanya sekarang ini kita bisa melihat disekitar kita bahwa anakanak jauh lebih bisa dari orang dewasa dalam hal mengoperasikan gadget.

Gadget memang dapat memberikan banyak manfaat bagi setiap orang termasuk anak-anak, bahkan dengan adanya gadget anak-anak banyak yang tertarik untuk menggunakan gadget dan anak-anak juga bisa menjadi ketagihan dalam menggunakan gadget. Sementara kalau dilihat dari asosiasi dokter anak Amerika dan Canada yang menjelaskan bahwa penggunaan gadget pada anak perlu diatur untuk durasinya. Pada anak usia 3-5 tahun 1 jam perhari dan pada usia 6-18 tahun 2 jam perhari. Adanya penggunaan gadget lebih dari waktu yang ditentukan akan membawa beberapa efek negatif yaitu, anak akan menjadi malas untuk bergerak. Anak akan cenderung lebih senang dengan gadgetnya sendiri dan tidak mau bersosialisasi(Rowman). Durasi waktu 301 jam pada anak merupakan waktu yang ideal dalam bermain gadget. Penggunaan gadget pada anak di bawah 2 tahun sangat tidak disarankan, bahkan tidak boleh sama sekali. ${ }^{3}$ Berikut ini adalah kasus anak yang kecanduan gadget:
Kasus adiksi atau kecanduan gawai kalangan anak-anak di Jawa Barat cukup memprihatinkan. Akhir Februari lalu, siswa SMP kelas 1 di Subang meninggal diduga penyebabnya karena kecanduan game. Tak hanya itu, jumlah pasien anak yang kecanduan gawai di RS Jiwa Cisarua Bandung Barat meningkat.

Raden Tri Sakti (12), siswa SMP kelas 1 asal Desa Salam Jaya, Pabuaran, Subang meninggal dunia dengan diagnosa mengalami gangguan syaraf. Pihak keluarga menyebut penyakit yang dideritanya dikabarkan karena kecanduan bermain game online di telepon seluler. Raden meninggal 23 Februari.

Endang, paman Raden, menceritakan keponakannya sejak awal tahun mengeluhkan sakit kepala, bahkan tangan dan kakinya susah digerakkan. Sempat dirawat selama di RS Siloam, Endang mengatakan dokter yang merawatnya mengatakan gangguan saraf yang diderita keponakannya itu karena radiasi telepon seluler. Endang menuturkan keponakannya selama ini selalu bermain game online seharian, ditambah dengan sekolah jarak jauh yang otomatis selalu memegang handphone. "Jadi anak itu

\footnotetext{
${ }^{3}$ Monografi Fenomena Kecanduan Gadget Pada Ansk Usia Dini (surabaya, 2020), 13.
} 
tadinya sering main HP game online siang malam, tidur subuh pukul 03.00 WIB.

Trus kerap mengigau kaya lagi bermain game," ujar Endang. ${ }^{4}$

Adapun pengaruh positif dari penggunaan gadget:

\section{Pengaruh Positif}

\section{Mempermudah komunikasi}

Dampak positif dari gadget yaitu, dapat mempermudah komunikasi antara satu dengan yang lainnya, kapanpun dan dimana saja. Seperti halnya dalam dunia pendidikan komunikasi antara guru dan pelajar dan juga komunikasi antara pelajar dan orang tua akan bisa berjalan dengan lebih gampang karena adanya gadget. Bahkan komunikasi bisa dilakukan dengan siapa saja melalui grup yang tersedia di aplikasi komunikasi, seperti whatsapp, facebook atau instagram.

Dengan adanya telepon genggam, dapat mengurangi resiko terbatasnya penyampaian ataupun penerimaan informasi dari satu orang ke orang berikutnya, seperti yang sering terjadi sebelum adanya telepon genggam, informasi sering kali tidak tersampaikan kepada orang yang dituju ataupun orang tidak bisa menerima informasi dengan cepat, dikarenakan belum adanya gadget atau telepon genggam.

Proses berbagi informasi atau melakukan video pertemuan untuk mengerjakan tugas juga dapat dilakukan di mana saja dan kapan saja dengan bantuan gadget, dan hal ini bisa sangat membantu dalam proses belajar. Contohnya dalam mengerjakan tugas kelompok, mungkin ada anak yang tidak bisa datang untuk bertemu secara langsung dengan teman kelompoknya, tetapi anak tersebut tetap dapat mengikuti proses mengerjakan tugas kelompok melalui grup komunikasi yang telah di buat melalui gadget atau handphone.

\section{Media hiburan}

Handphone mempunyai banyak karakteristik hiburan dan ini dapat menjadi alat untuk membantu para pelajar dan juga guru untuk beristirahat sebentar dari kebosanan antara pelajar dan juga pengajar.

Banyak aplikasi hiburan yang bisa menjadi alat untuk belajar sekaligus bermain bagi pelajar dan pengajar.

Contohnya permainan yang dapat meningkatkan kemampuan murid-murid yang dapat dilakukan dalam kehidupan

${ }^{4}$ https://apps.detik.com/detik/ 
pelajar, atau permainan yang mengasah kemampuan mengingat atau berhitung.

\section{Meningkatkan pengetahuan}

Salah satu pengaruh positif dari gadget khususnya handphone adalah dapat menolong para murid dalam memperoleh pengetahuan yang baru, dan handphone juga dilengkapi dengan berbagai aplikasi yang dapat menolong para murid untuk mendapatkan pengetahuan baru, dengan demikian anak-anak dapat dengan mudah belajar secara mandiri dengan mencari berbagai informasi di gadget yang mereka pegang. seperti google, murid-murid dapat mengakses berbagai informasi dan mengecek kesaksamaan informasi yang telah di kumpulkan oleh pelajar.

Hal ini sangat menolong para murid dalam mengerjakan tugas-tugas yang diberikan dan dapat meningkatkan pengetahuan dalam diri para murid dan membantu murid-murid untuk meningkatkan prestasi akademik mereka.

\section{Meningkatkan kenyamanan dalam}

\section{belajar}

Banyak pelajar dan juga pengajar yang telah merasa sangat nyaman dengan penggunaan handphone saat belajar daripada harus menghabiskan banyak waktu para murid dalam mencari sumber informasi yang mereka perlukan dengan pergi ke perpustakaan.

Handphone membantu murid-murid untuk menghemat banyak waktu dengan satu kali klik saja di dalam kamar mereka dan dapat memanfaatkan waktu mereka untuk melakukan hal-hal lain seperti belajar atau berkomunikasi dengan teman, keluarga atau guru dari para pelajar dalam waktu yang bersamaan. ${ }^{5}$

Selain pengaruh positif dari gadget, berikut ini ada juga pengaruh negatif dari penggunaan gadget.

Pengaruh Negatif

\section{Tidak fokus saat belajar}

Para siswa bisa saja tidak fokus saat belajar dikarenakan perhatian mereka telah dialihkan ke smartphone yang mereka miliki. Dan kadang perhatian mereka akan berpindah dengan melihat pesan teks, dan bermain games, atau hanya sekedar mengecek media sosial.

Dan bukan lagi hal yang dipungkiri bahwa smartphone memiliki kemampuan daya tarik yang membuat banyak sekali murid

\footnotetext{
${ }^{5}$ https://ybkb.or.id/dampak-positif-dan-negatifsmartphone-di-dunia-pendidikan
} 
yang melewatkan beberapa pelajaran yang diberikan karena terlalu sibuk dengan handphone mereka.

\section{Dapat menyebabkan kecanduan}

Smartphone dapat membuat murid-murid kecanduan dan tidak mau lepas dari smartphne mereka. Sejak dari bangun tidur sampai kembali mau tidur.

Smartphone menjadi hal utama yang mereka cari dan ini membuat satu kebiasaan baru, yang membuat para murid mengalami ketakutan, yaitu ketakutan yang muncul karena seseorang harus berpisah dengan smartphone mereka.

Ketakutan-ketakutan tersebut muncul karena sifat ketagihan yang dirasakan oleh para murid. Kegelisahan akan muncul jika mereka kehilangan smartphone, karena kehabisan baterai atau tidak ada sinyal yang berdampak kepada proses belajar mereka.

Sebuah penelitian menyebutkan bahwa ada $58 \%$ dari laki-laki dan $47 \%$ dari perempuan menderita nomophobia atau rasa takut kehilangan dan 9\% diantaranya merasa tertekan jika smartphone mereka mati.

\section{Kurangnya interaksi sosial di kehidupan nyata}

Dengan adanya banyak media sosial, menyebabkan banyak perubahan dalam diri anak-anak yang membuat mereka lebih mengarahkan perhatian kepada apa yang mereka lihat atau cari di smartphone yang mereka miliki, sehingga membuat interaksi atau hubungan sosial anak-anak dengan orang-orang yang ada disekitar mereka mulai berubah.

Hal inilah yang menyebabkan interaksi sosial di kehidupan mereka mulai berkurang. Karena mereka lebih senang berinteraksi melalui media sosial di bandingkan dengan memperkuat relasi dengan orang-orang yang ada disekitar mereka, dan sesungguhnya smartphone yang mereka miliki selalu berakibat mengganggu hubungan dengan teman, keluarga dan juga mengganggu prestasi akademik karena lebih fokus bermain dengan smartphone mereka daripada memilih untuk belajar.

\section{Prestasi akademik menurun}

Penggunaan smartphone secara tidak tepat dapat menyebabkan prestasi akademik menurun. Dan salah satu penyebabnya yaitu karena mereka tidak dapat mengingat atau menangkap informasi yang diberikan saat proses belajar 
mengajar karena perhatian mereka teralih oleh smartphone mereka.

\section{Membuat Anak kurang berempati dengan lingkungan sekitar}

Biasanya orang-orang yang sudah kecanduan dengan smartphone, akan cenderung lebih cuek dan kurang peduli dengan apa yang terjadi di sekitar mereka, mereka bisa saja bersikap acuh tak acuh dengan keadaan sekitar mereka karena sudah asyik dengan handphone mereka.

Contohnya, disaat ada acara pertemuan dengan keluarga atau teman-teman, ada begitu banyak dari anak-anak maupun orang dewasa yang malah lebih memilih asik dengan bermain smartphone mereka. Daripada saling bertukar kabar serta cerita dengan orang-orang yang ada di sekitar mereka. ${ }^{6}$

Dari kasus diatas beserta pengaruh positif dan negatif dari kecanduan gadget, bisa kita ketahui bahwa pengaruh gadget itu sangat besar. Oleh sebab itu orang tua sangat berperan penting dalam mendampingi anak dalam penggunaan gadget, sehingga orang tua dapat mengetahui apa saja yang dilihat atau yang dicari anak saat menggunakan gadget. Anak-anak bisa mencari apa saja

\footnotetext{
${ }^{6}$ https://ybkb.or.id/dampak-positif-dan-negatifsmartphone-di-dunia-pendidikan/
}

yang mereka ingin tahu di gadget, dan seperti yang kita ketahui bersama bahwa dalam penggunaan gadget ada hal positif dan hal negatifnya, karena itu orang tua harus benar-benar memastikan anak-anak dalam penggunaan gadget, sehingga anakanak tidak terpengaruh ke hal-hal yang negatif.

\section{METODE PENELITIAN}

Dalam penelitian ini, akan menggunakan metode penelitian Pustaka. Dan riset pustakaan membatasi kegiatannya hanya pada bahan-bahan koleksi perpustakaan saja tanpa memerlukan riset lapangan. metode penelitian kepustakaan adalah kegiatan pengumpulan data Pustaka, membaca dan mencatat serta mengolah bahan penelitian. ${ }^{7}$

Tujuan penelitian yaitu, pertama, untuk mendapatkan deskripsi tentang gadget. Kedua, untuk mendapatkan deskripsi tentang fungsi gadget. Keempat, untuk mendapatkan deskripsi penggunaan gadget Pada Anak 5-6 tahun. Kelima, untuk mendapatkan deskripsi tentang dampak positif dan dampak negatif penggunaan gadget pada anak usia 5-6 tahun. Keenam, untuk mendapatkan deskripsi tentang cara mengajarkan penggunaan gadget yang baik pada anak usia dini. Ketuju, untuk

\footnotetext{
${ }^{7}$ Metode Penelitian Kepustakaan (jakarta, 2008),
} 3. 
mendapatkan deskripsi tentang teknis pendampingan anak usia 5-6 tahun dalam penggunaan gadget.

\section{HASIL DAN PEMBAHASAN}

\section{Pengertian Gadget}

Secara umum, gadget merupakan alat elektronik yang berukuran relative kecil serta mempunyai manfaat khusus serta praktis dalam penggunaannya. Sedangkan Pendapat lain mengatakan bahwa gadget merupakan benda elektronik yang berukuran kecil yang dapat dibawah kemana saja dengan mudah. Gadget adalah alat elektronik portable karena dapat digunakan tanpa harus terhubung dengan stop kontak beraliran listrik. ${ }^{8}$

Gadget adalah salah satu bagian dari perkembangan teknologi yang dapat mempermudah pekerjaan manusia. Dengan kata lain, teknologi adalah bahasa secara umumnya, sedangkan gadget adalah bahasa khususnya. Salah satu hal yang membedakan gadget dengan perangkat elektronik lainnya adalah bagian kebaruannya, artinya, bahwa dari hari kehari gadget selalu muncul dengan memberikan teknologi terbaru yang

\footnotetext{
${ }^{8}$ Mengatasi Kecanduan Gadget Pada Anak, n.d.,
} 1. membuat hidup manusia menjadi lebih berdaya guna. ${ }^{9}$

Berdasarkan definisi gadget di atas, dapat disimpulkan bahwa gadget adalah alat yang dapat digunakan untuk mengakses berbagai informasi, dan juga dapat digunakan untuk memberikan informasi, serta gadget merupakan alat yang memberikan kemudahan bagi pengguna untuk saling berinteraksi satu dengan yang lainnya.

\section{Fungsi Gadget}

Fungsi utama dari kehadiran gadget adalah agar dapat memudahkan segala pekerjaan manusia. Contohnya seperti, kemudahan dalam berkomunikasi, mencari informasi, dan lain-lain. Gadget merupakan hal yang sangat penting dan juga membantu untuk memudahkan pekerjaan manusia, jika manusia yang menggunakan gadget dapat mempergunakannya sebaik mungkin ${ }^{10}$. Berikut ini beberapa fungsi gadget yaitu:

\section{Media komunikasi}

Gadget berfungsi sebagai media komunikasi, yang dapat memudahkan manusia untuk saling berinteraksi satu dengan yang lainnya melalui media sosial seperti smartphone. Dengan adanya smartphone manusia dapat saling

\footnotetext{
${ }^{9}$ Ibid., 2.

10 Ibid., 2-3.
} 
berkomunikasi tanpa harus bertemu secara langsung, melalui perangkat komunikasi seperti smartphone, laptop, smart watch, dan lain-lainnya.

Menurut Eni Suprihatin, mengatakan bahwa Media Sosial merupakan alat atau sarana yang dapat digunakan untuk berkomunikasi dengan orang lain. Dalam dunia digital media sosial adalah aplikasi yang menggunakan internet yang memungkinkan penggunanya berinteraksi satu dengan yang lain dengan membuat informasi dan membagikannya serta menerima informasi dari pengguna lainnya. ${ }^{11}$

\section{Akses informasi}

Selain sebagai media komunikasi, gadget juga berfungsi sebagai alat untuk mengakses berbagai informasi yang terdapat di internet. ${ }^{12}$

\section{Media hiburan}

Beberapa jenis gadget dibuat khusus untuk tujuan hiburan. Misalnya ipod untuk mendengar musik dan smartphone yang dapat membuka video. ${ }^{13}$

\section{Gaya hidup}

Gadget sudah menjadi bagian penting kehidupan manusia saat ini. Boleh

\footnotetext{
${ }^{11}$ Eny suprihatin, "Kontekstualisasi Roma 12:2 Dalam Keniscayaan Dunia Digital" (n.d.).

${ }^{12}$ Mengatasi Kecanduan Gadget Pada Anak, 3.

13 Ibid.
}

$\begin{array}{llrr}\text { dikatakan bahwa gadget } & \text { akan } \\ \text { mempengaruhi gaya } & \text { hidup setiap } \\ \text { penggunanya. }^{14} & & & \end{array}$

\section{Jenis gadget}

Berbicara menegenai gadget, pastinya yang pertama kali muncul dalam pikiran kita adalah handphone, tetapi sesungguhnya gadget tidak hanya ada satu macam saja, namun ada berbagai macam. Berikut ini beberapa jenis gadget yaitu:

\section{Handphone}

Handphone merupakan jenis gadget yang paling banyak digunakan oleh hamper semua masyarakat saat ini. Fungsi utamanya adalah sebagai alat komunikasi, namun seiring berkembangnya zaman terdapat funsi lain seperti untuk mencari informasi, game, membuat video, dan masih banyak lagi fungsi lainnya. ${ }^{15}$

\section{Laptop}

Laptop merupakan jenis gadget lainnya yang sangat sering digunakan untuk berbagai keperluan, terutama untuk pekerjaan. Gadget ini juga membutuhkan operating system agar dapat berjalan, seperti windows, mac, linux, dan lainlain. ${ }^{16}$

\footnotetext{
14 Ibid.

15 Ibid., 4.

16 Ibid.
} 
Tablet dan ipad

Jenis gadget ini merupakan bentuk yang lebih besar dari handphone. Dengan ukuran layar yang lebih besar dari handphone, tablet dan ipad dapat menampilkan gambar yang lebih besar dan jelas sehingga pengguna lebih nyaman Ketika ingin menonton, bermain game, dan juga kegiatan lainnya. ${ }^{17}$

\section{Kamera digital}

Kamera digital termasuk dalam ketegori gadget. Kegunaan kamera digital adalah untuk menangkap gambar suatu objek, baik dalam bentuk foto maupun video. $^{18}$

\section{Penggunaan Gadget Pada Anak Prasekolah}

Bukan hal yang asing lagi bagi setiap kita, bahwa di zaman sekarang ini yang bisa dan tahu menggunakan gadget bukan hanya orang tua atau orang dewasa saja, tetapi anak-anak yang masih kecilpun justru jauh lebih pintar dalam menggunakan gadget. Bahkan karena terlalu banyaknya hal-hal yang menarik atau yang terdapat dalam gadget, tidak heran lagi bahwa banyak anak-anak yang sangat kecanduan dengan gadget. Padahal pada usia anak yang masih kecil tidak

17 Ibid.

18 Ibid. dibolehkan untuk menggunakan gadget seperti handphone,dan lain-lain. Bahkan ada pendapat yang mengatakan bahwa anak dibolehkan menggunakan gadget itu di usia remaja. Namun karena zaman yang semakin maju dan juga kurangnya pemahaman orang tua atau orang dewasa tentang kapan anak boleh memegang handphone, sehingga banyak orang tua atau orang dewasa yang membiarkan anak-anak memegang dan menggunakan gadget sebelum waktunya. ${ }^{19}$

Berikut ini menurut penelitian yang dilakukan oleh Rideout, didapatkan hasil bahwa terdapat anak prasekolah dapat bermain gadget kurang lebih 2 jam perhari, dan usia sekolah bisa menghabiskan waktu kurang lebih 3 jam $^{20}$. Berikut ini durasi penggunaan gadget: total waktu dalam penggunaan gadget harus dipertimbangkan oleh orang tua, dan seharusnya orang tua mengambil Tindakan yang tepat yaitu dengan memberikan aturan kepada anak dalam penggunaan gadget. Apalagi pada anak prasekolah, hal ini bila anak menggunakan gadget secara terusmenerus, maka akan berdampak pada perkembangan anak (Starburger, 2011). Durasi dalam menggunakan gadget seorang anak hanya boleh berada didepan layar kurang lebih 1 jam setiap harinya

\footnotetext{
${ }^{19}$ Monografi Fenomena Kecanduan Gadget Pada Anak Usia Dini (surabaya, 2020), 13.

20 Ibid., 14.
} 
(Starburger, 2011). Hal ini sama dengan asosiasi dokter anak Amerika dan Canada yang menjelaskan bahwa penggunaan gadget pada anak perlu diatur untuk durasinya. Pada anak usia 3-5 tahun 1 jam perhari dan pada usia 6-18 tahun 2 jam perhari $^{21}$.

Adanya penggunaan gadget lebih dari waktu yang ditentukan akan membawa beberapa efek negative yaitu, anak akan menjadi malas untuk bergerak. Anak akan cenderung lebih senang dengan gadgetnya sendiri dan tidak mau bersosialisasi. Durasi waktu 30-1 jam pada anak merupakan waktu yang ideal dalam bermain gadget. Penggunaan gadget pada anak di bawah 2 tahun sangat tidak disarankan, bahkan tidak boleh sama sekali. $^{22}$

\section{Dampak positif penggunaan gadget pada anak usia 5-6 tahun}

Dalam penggunaan gadget terdapat dampak posetif jika digunakan dengan baik. Berikut ini beberapa dampak positif dari penggunaan gadget bagi anak, menurut Indiana Sunita,dkk (2017:66):

\section{Menambah pengetahuan}

Bukan hal yang diragukan lagi bagi anak-anak khususnya dalam penggunaan gadget, mereka sudah jauh lebih mahir dalam penggunaan gadget, apalagi anak-

\footnotetext{
21 Ibid.
}

anak yang di usia 5-6 tahun. Anak-anak dapat memperoleh informasi dengan mudah dan cepat. Misalnya Ketika anakanak ingin mengetahui tentang suatu hal, mereka bisa langsung browsing di internet kapanpun dan dimanapun, karena melalui internet bisa menambah pengetahuan anakanak dari berbagai sumber.

\section{Memperluas jaringan persahabatan}

Salah satu dampak positif gadget adalah dapat memperluas jaringan persahabatan atau pertemanan karena dapat bergabung di media sosial dengan mudah dan cepat, karena itu dapat berbagi dengan mudah Bersama keluarga, dan temanteman dimanapun dan kapanpun.

\section{Mempermudah komunikasi}

Gadget merupakan salah satu alat yang memiliki teknologi yang canggih. Jadi semua orang dapat dengan mudah berkomunikasi dengan orang lain dari seluruh penjuru dunia.

\section{Melatih kreativitas anak}

Kemajuan teknologi telah menciptakan beragam permainan yang kreatif dan menantang. Banyak anak yang termasuk kategori ADHD diuntungkan oleh permainan ini oleh karena tingkat kreativitas dan tantangan yang tinggi.

\footnotetext{
${ }^{22}$ Sylvie Puspita, Monografi Fenomena Kecanduan Gadget Pada Anak Usia Dini.
} 
ADHD adalah attention deficit hyperactivity disorder yang merupakan gangguan perkembangan dalam peningkatan aktivitas motorik anak-anak hingga menyebabkan aktivitas anak-anak yang tidak lazim dan cenderung berlebihan.

\section{Beradaptasi dengan zaman}

Dampak positif gadget akan membantu perkembangan anak agar bisa menyesuaikan diri dengan keadaan lingkungan sekitar dan perkembangan zaman sekarang muncul gadget, maka anakpun harus tau cara menggunakannya diiringi dengan pengawasan yang dilakukan oleh orang tua.

\section{Berkembangnya imajinasi}

Berkembangnya imajinasi anak dengan melihat berbagai jenis gambar kemudian menggambarnya sesuai imajinasinya yang bertujuan untuk melatih daya anak sesuai dengan perkembangannya.

\section{Dampak Negatif Penggunaan Gadget}

\section{Pada Anak}

Selain dampak positif dalam penggunaan gadget, juga terdapat dampak negative. Berikut ini beberapa dampak negatif dari penggunaan gadget bagi anak:

\footnotetext{
${ }^{23}$ M.Pd Mhd, Habibu Rahman, M.Pd Rita Kencana, and S.Pd Nur Faizah, Pengembangan Nilai Moral
}

Mengganggu perkembangan anak

Gadget memiliki fitur canggih, misalnya kamera, permainan, video, dll. Fitur tersebut akan mengganggu proses pembelajaran sekolah, karena siswa dapat menggunakan gadget tidak semestinya dan akan berdampak pada perkembangan anak. $^{23}$

\section{Kesehatan otak terganggu}

Otak bagian depan seorang anak sebenarnya belum sempurna seperti orang dewasa. Menurut para ahli Kesehatan otak bagian depan seorang individu matang pada usia 25 tahun. Sementara fungsi otak bagian depan adalah pusat memerintahkan tubuh untuk melakukan pergerakan dan reseptornya yang mendukung otak depan adalah otak bagian belakang yang berfungsi menghasilkan hormone dopamine yang menghasilkan perasaan nyaman atau tenang. Jadi jika anak bermain gadget dan membuka informasi yang negative seperti pornografi atau kekerasan, maka informasi itu akan terekam dalam memori otak dan sulit untuk dihapus dari pikiran bahkan untuk waktu yang lama. Dan jika hal ini orang tua atau orang dewasa tidak segera diatasi maka anak akan kecanduan karena adanya hormone dopamin yang dihasilkan Ketika

Dan Agama Anak Usia Dini (tasikmalaya,jawa barat, 2020).hlm 88-90. 
melihat informasi pornografi atau kekerasan membuatnya nyaman.

\section{Kesehatan mata terganggu}

Sebuah penelitian menunjukkan bahwa Ketika individu membaca pesan teks atau browsing di internet melalui smartphone atau tablet cenderung bekerja lebih keras. Hal ini perlu diperhatikan terutama bagi orang tua yang memiliki anak yang berkaca mata. Sebab dengan jarak baca yang terlalu dekat maka mata anak yang berkaca mata akan bertambah bebannya. Akibatnya satuan minus kacamata akan bertambah. Kerja mata saat menggunakan gadget adalah memfokuskan dengan teks pada smartphone ataupun tablet hal itu jika dibiarkan akan menyebabkan sakit kepala dan tegang didaerah kelopak mata.

\section{Kesehatan tangan terganggu}

Ketika anak memainkan gadget seperti bermain video game dengan frekuensi yang tinggi biasanya akan mengalami kecapean dibagian tangan terutama bagian jari. Penyakit ini disebut oleh ahli Kesehatan dengan nama "sindrom vibrasi". Hal tersebut dikarenakan seorang anak memainkan game dengan memakai controller lebih dari tuju jam. Teknologi touchscreen memang memudahkan pengguna dalam menggunakan gadget. Tetapi posisi tangan saat penggunaan layer touchscreen akan mempengaruhi Kesehatan tangan. Semakin lama pengguna menekuk tangan maka semakin rawan pergelangan tangan anak cedera.

\section{Gangguan tidur}

Bagi anak yang kecanduan gadget tanpa adanya pengawasan orang tua ia akan selalu memainkan gadget. Bila itu dilakukan dan terjadi terus menerus tanpa adanya Batasan waktu maka akan mengganggu jam tidur anak. dan hal ini akan membuat anak terlambat bangun dan bisa jadi anak tidak akan berangkat kesekolah karena ia mengantuk, dan jika orang tua tidak segera bertindak maka hal ini akan menjadi kebiasaan bagi anak. oleh sebab itu agar hal ini tidak terjadi maka orang tua harus bijak dalam membuat peraturan dirumah,orang tua sebaiknya buat kesepakatan bersama anak seperti kapan anak makan, tidur, belajar, dan bermain gadget.

\section{Suka menyendiri}

Ketika anak sudah merasa asyik bermain gadget makai a akan merasa itu adalah segalanya. Anak tidak akan peduli lagi dengan apa yang ada disekitarnya, karena yang dibutuhkan adalah bermain dengan gadgetnya dan dilakukannya sendiri tanpa butuh teman. Disekolah Ketika anak harus bertemu dengan temantemannya ia akan sulit berinteraksi ataupun 
berkomunikasi secara sehat, sebab konsentrasinya hanya kepada gadget yang menyajikan berbagai hal menarik daripada bergaul. Dan ia akan kesulitan untuk fokus dan akhirnya ia menjadi anak yang menyendiri.

\section{Perilaku kekerasan}

Menurut penelitian perilaku kekerasan yang terjadi pada anak dikarenakan anak sering mengonsumsi materi kekerasan baik itu melalui game atau media yang menampilkan kekerasan. Hal ini akan sangat mempengaruhi pikiran dan tingkah laku anak, jika anak terus bermain game yang mengandung unsur kekerasan, dan kebanyakan orang tua memberikan gadget kepada anak dengan tujuan agar anak bisa duduk tenang dirumah dan tidak mengganggu aktivitas orang tua, namun perlu diketahui bahwa Ketika anak yang bermain gadget tidak didampingi oleh orang dewasa maka bisa jadi anak akan membuka game-game yang mengandung unsur kekerasan. Oleh sebab itu untuk mengatasi hal ini maka orang tua harus berada disamping anak saat anak sedang bermain gadget, dan orang tua juga harus memastikan apa saja yang dilihat oleh anak saat menggunakan gadget, bila perlu orang tua memilihkan game yang bermanfaat bagi anak, sehingga anak tidak memainkan game yang memiliki unsur-unsur negatif.

\section{Pudarnya kreativitas}

Dengan adanya gadget, kecenderungan anak menjadi kurang kreatif lagi. Itu dikarenakan Ketika ia diberi tugas oleh sekolah ia tinggal browsing di internet untuk menyelesaikan tugasnya. Gadget memang memudahkan anak untuk belajar, namun disisi lain kreativitas anak akan terancam pudar jika anak terlalu bergantung dengan perangkat tersebut.

\section{Terpapar radiasi}

Sebuah gadget seperti laptop sebenarnya memancarkan radiasi namun radiasi ini berfrekuensi rendah. Efek yang ditimbulkan Ketika bermain laptop terlalu lama biasanya mengakibatkan mata berair karena kelelahan mata. Beberapa pakar Kesehatan mengatakan bahwa radiasi smartphone menimbulkan ancaman penyakit seperti tumor otak, kanker, Alzheimer dan Parkinson. ${ }^{24}$

Gadget memang sangat membantu dan memudahkan anak dalam belajar, namun dalam penggunaan gadget ada hal negatif dan hal positifnya, dan itu semua tergantung dari setiap orang yang menggunakannya. Jika orang yang menggunakan gadget untuk hal-hal yang

\footnotetext{
${ }^{24}$ Derry Iswidharmanjaya\&Beranda Agency, Si Kecil Bermain Gadget, 2014.hlm 17-28.
} 
positif maka akan memperoleh pengaruh yang positif, tetapi jika orang yang mengunakan gadget mempergunakan untuk hal-hal yang negatif, maka orang tersebut akan mendapatkan pengaruh yang negatif. Dan karena dalam penggunaan gadget ada hal baik dan ada hal buruknya, maka Ketika anak-anak menggunakan gadget orang tua harus mendampingi anak tersebut agar anak tidak terpengaruh kehalhal negatif.

\section{Cara mengajarkan penggunaan gadget} yang baik untuk anak usia dini

Setiap orang tua pasti menginginkan anak-anaknya menjadi pengguna gadget yang baik, oleh karena itu orang tua perlu memberikan pengajaran atau contoh penggunaan gadget yang baik kepada anak.

Eny Suprihatin mengatakah bahwa Tuhan menginginkan agar semua orang yang percaya kepada Tuhan, tidak lagi hidup sama seperti dunia ini, sekalipun manusia masih berada dalam dunia. Dan jika seorang kristen tidak berjaga-jaga maka seorang kristen dapat menjadi sama dengan dunia ini. Roh Kudus disediakan bagi orang-orang yang mau hidup dengan dunia baru. Dua hal yang dapat terjadi bagi seseorang yang percaya kepada Yesus
Kristus. Pertama, akan berubah cara pandang dan gaya hidupnya menurut dunia yang baru sehingga tidak nyaman di dunia ini. Kedua, menyesuaikan dengan tata aturan dunia ini, sehingga tidak nampak perubahan pikir dan perilakunya. Jadi ada yang makin berkembang ke arah dunia yang akan datang, atau sebaliknya menjadi semakin serupa dengan dunia ini. ${ }^{25}$

Berikut ini ada cara mengajarkan penggunaan gadget yang baik untuk anak usia dini, yang dapat digunakan orang tua sebagai fasilitatot edukasi dalam menyampaikan penggunaan gadget yang baik pada anak:

Langkah: pastikan anak siap untuk menerima materi. Perhatikan cara mengawali edukasi ke anak termasuk Bahasa, posisi tubuh, dan intonasi suara.

Contoh penyampaian pada anak: tanyakan saat anak selesai melakukan rutinitas, seperti setelah makan malam, dan usahakan jangan mengajak anak ngobrol saat pulang sekolah, biarkan anak istirahat dan membersihkan tubuhnya terlebih dahulu. Dan saat mengajak anak ngobrol pastikan posisi duduknya teratur dan tidak mengganggu kenyamanan anak maupun orang tua. Pastikan posisi tubuh orang tua sejajar dengan posisi tubuh anak, misalnya

\footnotetext{
25 “Kontekstualisasi Roma 12:2 Dalam Keniscayaan Dunia Digital," 131.
} 
jika anak duduk orang tua juga harus duduk, dan kalau anak berdiri orang tua boleh membungkukkan badan dan mengajak anak untuk duduk, dan tataplah mata anak, orang tua juga tidak boleh melakukan kegiatan lain saat mengajak anak berbicara, seperti main hp dan aktivitas lainnya.

Minta anak untuk merefleksikan bagaimana penggunaan gadget anak setiap hari. Kemudian tanyakan apakah penggunaannya sudah baik atau belum, dan mintalah anak untuk menjelaskan alasannya. Contoh penyampaian pada anak: "kalau menurutmu, apakah hpnya sudah digunakan dengan baik?” Tunggulah respon dari anak, dan jika anak menjawab ia atau tidak, maka orang tua tanyakan alasan anak, lalu berikan penjelasan. "jadi ya nak, kalau menggunakan gadget/hp/tablet/laptop yang baik itu adalah harus didampingi sama ayah/ibu, dan juga ada batas waktunya dalam menggunakan hp yaitu paling lama 3o menit setiap hari, dan tidak semua hal di gadget kamu buka, dan juga kalau menggunakan gadget harus izin terlebih dahulu sama ayah/ibu, dan gadget adalah alat yang membantu kamu untuk belajar ya nak, jadi gunakanlah untuk hal-hal yang bermanfaat.

Rangsang anak untuk dapat mengulangi tentang manfaat gadget, dampak buruk penggunaan gadget yang berlebihan, dan cara menggunakan gadget dengan baik. Contoh penyampaian pada anak: "menurut kamu nak apa sih hal-hal baik dari menggunakan gadget?". Tunggu respon dari anak, lalu lanjut untuk menanyakan "kalau hal buruknya apa saja?”.

Setelah mengobrol santai dengan anak berisi materi, berikan ucapan dan pujian pada anak. contoh penyampaian pada anak: "terima kasih ya nak sudah mau ngobrol sama ayah/ibu mala mini. Kamu memang anak yang baik dan pintar". ${ }^{26}$

\section{Teknis pendampingan anak usia 5-6 tahun dalam penggunaan gadget}

Orang tua adalah guru pertama dalam mendidik anak. oleh sebab itu orang tua atau orang dewasa harus tahu teknis atau cara untuk mendampingi anak dalam penggunaan gadget. Mendampingi anak dalam penggunaan gadget adalah hal yang sangat penting, karena seperti yang kita telah ketahui Bersama bahwa gadget memang memiliki berbagai macam

\footnotetext{
${ }^{26}$ Vivian Nanny Lia Dewi, Mei Neni Sitaresmi, and Fatwa Sari Tetra Dewi, Save d'kids Modul Untuk Orang Tua (yogyakarta, 2020).hlm 48-50.
} 
manfaat dalam mempermudah pekerjaan manusia, tetapi gadget juga jika disalah gunakan maka yang kita dapatkan adalah hal yang negatif, apalagi jika anak-anak dibiarkan begitu saja dalam menggunakan gadget, maka mereka akan membuka apa saya yang mereka mau lihat, karena bukan hal yang mengherankan lagi di zaman sekarang anak-anak jauh lebih bisa dalam menggunakan gadget, jadi untuk mengatasi hal-hal yang tidak kita inginkan terjadi pada anak-anak, maka orang tua harus segera bertindak.

Berikut ini cara yang dapat dilakukan oleh orang tua dalam mengawasi dan mendampingi anak dalam penggunaan gadget:

\section{Belajar untuk tetapkan batas}

Orang tua perlu tetapkan batas waktu saat menggunakan teknologi untuk bekerja ataupun menikmati hiburan, dan jangan melanggarnya. Orang tua juga harus membatasi waktu anak dalam penggunaan gadget dirumah, dengan menyimpan password dan juga memblokir kontenkonten yang berisikan pornografi di smartphone.

Selalu berusaha untuk mendampingi anak saat menggunakan gadget.

Beri penjelasan tentang apa yang sedang dipelajari. Dan Ketika anak tertarik pada hal atau konten yang menurut orang tua kurang sesuai, beritahu anak mengapa konten tersebut baik dan mengapa konten yang lain tidak baik.

Orang tua disarankan menerapkan Gerakan 1821, yaitu melakukan puasa gadget selama 3 jam mulai dari jam 18:0012:00. Orang tua sebaiknya menghabiskan waktu Bersama anak sepenuh hati, selama 3 jam saja, dan orang tua bisa mengajak anak untuk bermain Bersama, menemani anak belajar, mengajak anak untuk berkomunikasi. Hendaknya orang tua berusaha untuk mengembalikan hak-hak anak yang telah dirampas oleh gadget.

\section{Jadilah teladan bagi anak}

Perilaku orang tua atau orang dewasa terhadap penggunaan gadget adalah contoh yang mudah sekali ditiru oleh anak. maka dari itu orang tua harus berikan teladan. yang baik bagi anak dalam penggunaan gadget.

\section{Carilah aplikasi yang berkualitas}

Pilihlah aplikasi yang sesuai dengan kesukaan dan bakat anak, sehingga anak bersemangat untuk melakukan eksplorasi pada hal-hal baru. Variasinya bisa beraneka ragam, seperti puzzle, cerita 
anak berkarakter, music permainan alpabet, game matematika, dan seni. ${ }^{27}$

\section{Kesimpulan}

Gadget merupakan salah satu bagian dari perkembangan teknologi yang selalu menghadirkan teknologi terbaru yang dapat membantu aktivitas manusia menjadi lebih mudah. Gadget dapat memberi berbagai macam informasi bagi informasi yang positif maupun informasi yang negative, dan itu semua bergantung pada orang yang menggunakan gadget, jika pengguna gadget menggunakan untuk tujuan yang positif maka akan memperoleh hal-hal yang bermanfaat, demikian juga jika pengguna memakai gadget untuk halhal yang negatif, maka hal-hal yang tidak bermanfaatlah yang akan didapatkannya.

Pada zaman sekarang ini bukan hanya orang tua atau orang dewasa saja yang dapat menggunakan gadget, tetapi anak-anak yang masih usia dini sudah sangat pintar dalam penggunaan gadget. Gadget memang memudahkan anak untuk belajar, untuk menjalin relasi dengan teman-temannya, mencari informasi, mendapatkan hiburan, dan juga masih banyak manfaat lain yang bisa diperoleh anak melalui gadget. Tetapi meskipun demikian gadget juga bisa memberi pengaruh buruk pada anak seperti gangguan Kesehatan, ketagihan dengan game-game yang menampilkan konten kekerasan, anak kurang berinteraksi secara langsung dengan teman-temannya atau orang yang ada disekitarnya, dan masih banyak lagi hal-hal negatif lainnya yang dapat mempengaruhi perkembangan anak. oleh sebab itu orang tua atau orang dewasa harus benar-benar tau cara mendampingi anak dalam penggunaan gadget sehingga anak tidak terjerumus kehal-hal yang kurang baik. 
DAFTAR PUSTAKA

Agency, Derry

Iswidharmanjaya\&Beranda. Si Kecil

Bermain Gadget, 2014.

Dewi, Vivian Nanny Lia, Mei Neni

Sitaresmi, and Fatwa Sari Tetra Dewi.

Save d'kids Modul Untuk Orang Tua.

yogyakarta, 2020.

Eka Anggraini. Mengatasi Kecanduan

Gadget Pada Anak, n.d.

Eny suprihatin. "Kontekstualisasi Roma

12:2 Dalam Keniscayaan Dunia

Digital" (n.d.).

Mestika Zed. Metode Penelitian

Kepustakaan. jakarta, 2008.

Mhd, Habibu Rahman, M.Pd, M.Pd Rita

Kencana, and S.Pd Nur Faizah.

Pengembangan Nilai Moral Dan

Agama Anak Usia Dini.

tasikmalaya,jawa barat, 2020.

Suryameng. "Pendampingan Dialogis

Orangtua Dalam Penggunaan Gadget

Pada Anak Usia Dini.” DUNIA

ANAK: Jurnal Pendidikan Anak Usia

Dini 2, no. 2 (2019): 40-49.

Sylvie Puspita. Monografi Fenomena

Kecanduan Gadget Pada Anak Usia

Dini. surabaya, 2020. . Monografi Fenomena Kecanduan

Gadget Pada Anak Usia Dini. surabaya, 2020.

Monografi Fenomena Kecanduan

Gadget Pada Ansk Usia Dini.

surabaya, 2020.

Agency, Derry

Iswidharmanjaya\&Beranda. Si Kecil

Bermain Gadget, 2014.

Dewi, Vivian Nanny Lia, Mei Neni

Sitaresmi, and Fatwa Sari Tetra Dewi.

Save d'kids Modul Untuk Orang Tua.

yogyakarta, 2020.

Eka Anggraini. Mengatasi Kecanduan

Gadget Pada Anak, n.d.

Eny suprihatin. "Kontekstualisasi Roma

12:2 Dalam Keniscayaan Dunia

Digital" (n.d.).

Mestika Zed. Metode Penelitian

Kepustakaan. jakarta, 2008.

Mhd, Habibu Rahman, M.Pd, M.Pd Rita

Kencana, and S.Pd Nur Faizah.

Pengembangan Nilai Moral Dan

Agama Anak Usia Dini.

tasikmalaya,jawa barat, 2020.

Suryameng. "Pendampingan Dialogis

Orangtua Dalam Penggunaan Gadget

Pada Anak Usia Dini.” DUNIA

ANAK: Jurnal Pendidikan Anak Usia

Dini 2, no. 2 (2019): 40-49.

Sylvie Puspita. Monografi Fenomena

Kecanduan Gadget Pada Anak Usia 
Dini. surabaya, 2020.

Monografi Fenomena Kecanduan

Gadget Pada Anak Usia Dini.

surabaya, 2020.
- Monografi Fenomena Kecanduan

Gadget Pada Ansk Usia Dini.

surabaya, 2020. 